\title{
German Energy and Decarbonization Scenarios: "Blind Spots" With Respect to Biomass-Based Carbon Removal Options
}

OPEN ACCESS

Edited by:

Mai Bui,

Imperial College London,

United Kingdom

Reviewed by:

Ajay Gambhir,

Imperial College London,

United Kingdom

Praveen Bains,

International Energy Agency, France

*Correspondence:

Alena Hahn

alena.hahn@dbfz.de

Daniela Thrän

daniela.thraen@ufz.de

Specialty section:

This article was submitted to Sustainable Energy Systems and

Policies,

a section of the journal

Frontiers in Energy Research

Received: 17 January 2020

Accepted: 27 May 2020

Published: 02 July 2020

Citation:

Hahn A, Szarka N and Thrän D (2020) German Energy and Decarbonization

Scenarios: "Blind Spots" With Respect

to Biomass-Based Carbon Removal

Options. Front. Energy Res. 8:130.

doi: 10.3389/fenrg.2020.00130

\begin{abstract}
Alena Hahn ${ }^{1 *}$, Nora Szarka ${ }^{1}$ and Daniela Thrän ${ }^{1,2,3 *}$
'Bioenergy Systems Department, DBFZ Deutsches Biomasseforschungszentrum (German Biomass Research Centre), Leipzig, Germany, ${ }^{2}$ Department of Bioenergy, Helmholtz Centre for Environmental Research - UFZ, Leipzig, Germany, ${ }^{3}$ Chair Bioenergy Systems, Institute for Infrastructure and Resources Management, Leipzig University, Leipzig, Germany
\end{abstract}

In 2019, the German government agreed on a Climate Protection Program intended to deliver its 2030 climate targets. Concrete measures, such as a carbon price, will be put in place as early as 2021. But how to plan beyond 2030? Scenarios can be powerful tools to envision the world in 20,30, or 50 years, to describe pathways toward different visions of the future, and ultimately to investigate technology portfolios and policy options against their performance toward the achievement of a decarbonized future. This is why scenarios are especially popular with energy and climate scholars. In particular, scenarios with biomass-based carbon removal options $\left(\mathrm{BCO}_{2}\right)$ can help to highlight how we may reach a net negative emission world. Hence, in this study, 66 energy and decarbonization scenario studies are systematically reviewed for Germany from the years 2002 to 2019 to assess how inclusive they are with regard to $\mathrm{BCO}_{2}$ concepts. The portfolio of $\mathrm{BCO}_{2}$ concepts within those scenarios is studied over time and a qualitative analysis of the scenario documentation is performed to identify the rationales for their inclusion or exclusion. The results indicate "blind spots" of the scenarios with regard to bioeconomy aspects, as biomass for material use is only sparsely covered. Likewise, only about $10 \%$ of the studies provide a framework for land use changes and corresponding emission accounting to adequately represent biomass-based negative emission technologies (NETs) in their assessments. The analysis for carbon capture and storage (CCS) further reveals the necessity of revisiting the public acceptance argument which has previously served so far for many studies as the ultimate, though not well-grounded deal-breaker. Based on the detected gaps and shortcomings in the current German scenario landscape, recommendations for a more transparent and holistic representation of $\mathrm{BCO}_{2}$ in the scenario framework are given.

Keywords: energy scenarios, Germany, negative emission technology (NET), Carbon Dioxide Removal (CDR), Bioenergy with Carbon Capture and Storage (BECCS), biogenic carbon, carbon capture and utilization (CCU), power-to-gas (PtG) 


\section{INTRODUCTION}

With the Paris Agreement of 2015, the international community of states has set itself stringent targets for the reduction of greenhouse gas (GHG) emissions. However, the agreement does not prescribe any specific measures-this is at the discretion of the respective states. In Germany, the federal government adopted the Climate Action Plan 2050 in November 2016, specifying its implementation strategy on national level: a longterm goal of GHG neutrality by 2050 and an intermediate target of at least 55 percent GHG emission reduction compared to 1990 by 2030. With its Climate Protection Program published in 2019, the German government further reaffirmed this ambition by outlining strategic policy ideas to reach the 2030 climate targets.

Energy and decarbonization scenarios can help to investigate technology options and regulatory measures that can make significant contributions to the achievement of these targets. Although scenarios are not projections or predictions of the future, they are internally coherent narratives that describe pathways toward different visions of the future. Due to their explorative character, energy and decarbonization scenarios should be as technology-open as possible, incorporating innovative concepts and emerging technologies.

A set of such technologies is Carbon Dioxide Removal (CDR), i.e., technologies and processes that absorb $\mathrm{CO}_{2}$ from the atmosphere. If the carbon thus obtained is not used but sequestered, then this concept is referred to as Negative Emission Technologies (NETs) due to their ability of removing more $\mathrm{CO}_{2}$ from the atmosphere over their entire lifecycle than emitting $\mathrm{CO}_{2}$, thus being net negative in their emissions balance. The most recent special report of the Intergovernmental Panel on Climate Change (IPCC) on the impacts of global warming of $1.5^{\circ} \mathrm{C}$ above pre-industrial levels (SR1.5) acknowledges the important role of NETs for stabilizing atmospheric $\mathrm{CO}_{2}$ concentrations (IPCC., 2018). However, most Integrated Assessment Models (IAMs) that submitted scenarios for consideration in the SR1.5 database are limited in their analysis to two NETs, namely Bioenergy with Carbon Capture and Storage (BECCS) ${ }^{1}$ and afforestation/reforestation. In fact, 9 out of 10 IAMs that successfully submitted scenarios explicitly model BECCS; 7 out of 10 consider afforestation/reforestation. In contrast, only two modeling frameworks directly address both Direct Air Capture and Storage (DACS) and Soil Carbon Sequestration (SCS). Restoration of wetlands and biochar are-if at all-only assessed implicitly and in an exogenous manner, i.e., they are not represented in any of these models but can be explored through comparison of multiple alternative scenarios. Similarly, ocean fertilization and enhanced weathering are not represented in any IAM reported by Forster et al. (2018).

To better understand potential challenges and synergies of biomass-based NETs, various scholars conducted more detailed

\footnotetext{
${ }^{1}$ If not explicitly stated otherwise, BECCS is understood in this paper as all kinds of bioenergy production combined with carbon capture and storage. It therefore encompasses dedicated bioenergy plants, biomass co-firing plants, biofuel production, and industrial uses of biomass, for example in the iron and steel industry.
}

analyses on subsets of NETs. In this regard, "biomass-based negative emissions" (Heck et al., 2018) or similar concepts such as "plant-based CDR" (Lenton, 2014a), "biomass-based CDR" (Turner et al., 2018), "land-based biological $\mathrm{CO}_{2}$ removal" (Lenton, 2014b), and also "terrestrial CDR (tCDR)" (Boysen et al., 2017) have been proposed for more refined assessments focusing mainly on BECCS, biochar, standing biomass, and to a lesser extent on biomass burial. Similarly, "natural climate solutions" (Griscom et al., 2017; Fargione et al., 2018) were assessed which consist in a set of 20 improved land management actions that increase the carbon sink function of forests, wetlands, grasslands, and agricultural lands. All these concepts compete for available land and available biomass. In fact, pathways for limiting global warming to $1.5^{\circ} \mathrm{C}$ might require the area of up to 12 million $\mathrm{km}^{2}$-representing the size of the entire European continent-to increase forest coverage in 2050 compared to 2010 levels (IPCC, 2019).

However, biomass-based NETs are not the only contenders for land and biomass. Food production, renewable energy provision, and some industries that rely on biomaterials also compete for these scarce resources. Therefore, a holistic approach is needed to address all biomass-based $\mathrm{CO}_{2}$ emissions reduction options (hereafter referred to as $\mathrm{BCO}_{2}$ concepts) that either (a) rely on the energetic or material use of biomass, (b) substitute fossil carbon sources and products through biogenic $\mathrm{CO}_{2}$, or (c) provide negative emissions based on biomass and land resources (Figure 1). Capturing the range of these concepts as comprehensively as possible in energy and decarbonization scenarios serves two main purposes: on the one hand, to assess their $\mathrm{CO}_{2}$ reduction and negative emissions potentials, and on the other hand, to identify possible competition for land and biomass use.

Taking Germany as case study, a structured review is carried out for 66 energy and decarbonization scenario studies from the years 2002 to 2019 to assess how inclusive they are with regard to $\mathrm{BCO}_{2}$ concepts. The evolution of the portfolio of $\mathrm{BCO}_{2}$ concepts within those scenarios is studied over time and a qualitative analysis of the scenario documentations is performed to identify the rationales for their (non-)inclusion. Furthermore, gaps in the scenario coverage of $\mathrm{BCO}_{2}$ options are addressed.

\section{METHODOLOGY}

In times of rapidly expanding scientific knowledge, the systematic review of published research serves multiple purposes at once: identifying and synthesizing the vast amount of studies to assess the state of science in a given field of knowledge and steer further progress in that field. By combining the results of relevant studies in a structured and transparent manner, this can further enhance the credibility of scientific assessments in general and allow for a more robust communication toward policymakers (Petticrew and McCartney, 2011; Minx et al., 2017).

In the more specific case of reviewing energy scenario studies, a systematic review can provide insights into the design of the future energy mix, $\mathrm{CO}_{2}$ mitigation options and driving factors for change. In addition, comparatively assessing scenario 


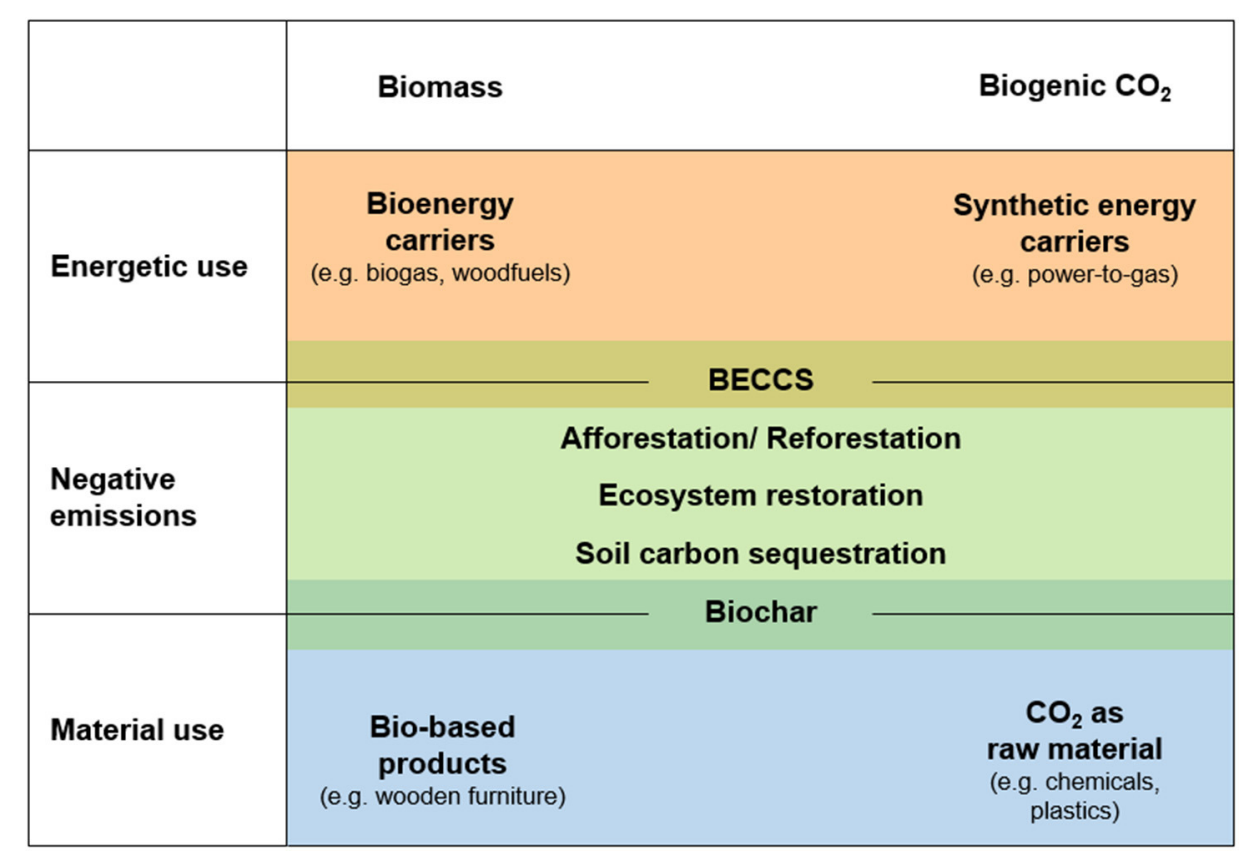

FIGURE 1 | Classification of biomass-based carbon removal options $\left(\mathrm{BCO}_{2}\right)$.

studies, their assumptions, and results enables highlighting system interdependences and evaluating different policy options. In fact, energy system and climate scholars regularly use scenario instruments to investigate possible future developments. By formulating fundamentally different assumptions for the future, scenarios can create awareness for uncertainties, opportunities, and risks associated with each of these possible futures.

For this study, a comprehensive list of German energy and decarbonization scenarios was established based on (a) study compilations of previous meta-analyses (Kronenberg et al., 2011; Haller et al., 2016; Peter et al., 2017; Szarka et al., 2017; Runkel, 2018; Samadi et al., 2019), (b) studies identified via scientific journals using Scopus and Web of Science, and (c) gray literature found via Google. Additionally, the reference lists of all identified documents were screened for collecting further scenario studies. The following word combinations were used as search terms, in both English and German: German* AND scenario* AND energy and climate change related terms ("energy system," "energy transition," "decarbonization," "climate change mitigation") AND the time horizons 2020-2100 in 5 year increments. Cutoff date for considering studies was November 2019, i.e., when performing the literature research. To qualify for the assessment, all scenario studies had to fulfill the following criteria:

- Explicit focus on either the energy transition ("Energiewende"), a $100 \%$ renewable energy system, or ambitious decarbonization and GHG reduction targets;

- Coverage of at least two of the three energy sectors, i.e., power, heat, and transport, thus excluding sector-specific studies;
- Quantification and/or modeling of the scenarios, therefore excluding Del phi surveys (BDEW, 2016) and expert elicitation of future trends and policy measures (BMU, 2016; Renn, 2017) for comparability reasons.

A catalog of the identified studies is shown in Table $\mathbf{1}$ with key information on their respective year of publication, source of funding, investigated scenarios and time horizon.

For the analysis, all scenario-based studies were screened for biomass-related carbon removal options as conceptualized in Figure 1. Both qualitative and quantitative mentions of all $\mathrm{BCO}_{2}$ concepts were gathered. Information was collected on whether they were (a) mentioned at all, (b) excluded on purpose, (c) considered within the scenario narratives, and/or (d) quantitatively assessed as part of the scenario modeling.

Additionally, with respect to the energetic and material use of biomass, all studies were screened for their biomass potentials, sectoral coverage of biomass use, imports, and sustainability considerations. For the energetic and material use of biogenic $\mathrm{CO}_{2}$, data was systematically gathered on $\mathrm{CO}_{2}$ supply volumes from both biogenic and other sources, as well as on $\mathrm{CO}_{2}$ utilization pathways in the energy and industrial sectors. The $\mathrm{BCO}_{2}$-focused analysis extends to non-biogenic $\mathrm{CO}_{2}$ sources as the latter ones can be used interchangeably in subsequent $\mathrm{CO}_{2}$ utilization applications. Furthermore, alongside information on BECCS, data was also gathered on fossil carbon capture and storage (CCS), industrial CCS and direct air capture with carbon storage (DACCS) as their concepts are similar to BECCS in terms of infrastructure requirements and geological storage. This was further combined with the collection of arguments within the studies for/against the use of CCS. Finally, references 
TABLE 1 | Overview and characteristics of the reviewed scenario studies.

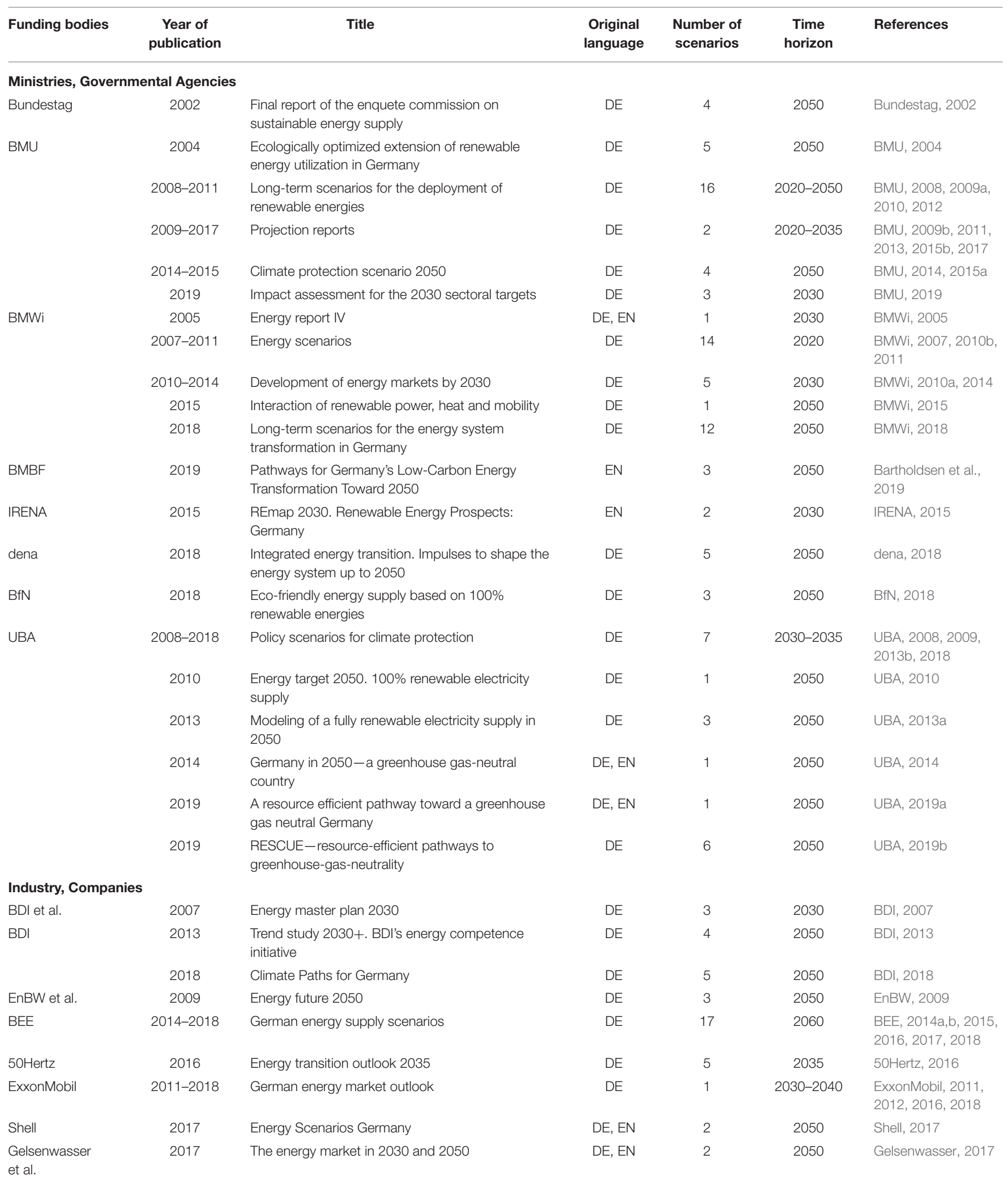


TABLE 1 | Continued

\begin{tabular}{|c|c|c|c|c|c|c|}
\hline Funding bodies & $\begin{array}{c}\text { Year of } \\
\text { publication }\end{array}$ & Title & $\begin{array}{l}\text { Original } \\
\text { language }\end{array}$ & $\begin{array}{l}\text { Number of } \\
\text { scenarios }\end{array}$ & $\begin{array}{c}\text { Time } \\
\text { horizon }\end{array}$ & References \\
\hline \multicolumn{7}{|c|}{ Ministries, Governmental Agencies } \\
\hline SRU & 2011 & $\begin{array}{l}\text { Pathways toward a } 100 \% \text { renewable electricity } \\
\text { system }\end{array}$ & DE, EN & 8 & 2050 & SRU, 2011 \\
\hline BUND & 2015 & $\begin{array}{l}\text { Fundamental concepts for the energy transition } \\
2050\end{array}$ & $\mathrm{DE}$ & 1 & o.J. & BUND, 2015 \\
\hline Greenpeace & $2007-2015$ & Climate protection plan for Germany & $\mathrm{DE}$ & 3 & $2020-2050$ & $\begin{array}{l}\text { Greenpeace, 2007, } \\
2010,2015\end{array}$ \\
\hline Greenpeace & 2018 & $\begin{array}{l}\text { How can Germany still achieve its climate target? } \\
\text { Energy scenario } 2020\end{array}$ & DE & 2 & 2020 & Greenpeace, 2018 \\
\hline \multirow[t]{3}{*}{ Fraunhofer ISE } & 2012 & $\begin{array}{l}100 \% \text { renewable energy for power and heat in } \\
\text { Germany }\end{array}$ & DE & 3 & 2050 & Fraunhofer ISE, 2012 \\
\hline & 2013 & Energy system Germany 2050 & DE & 1 & 2050 & Fraunhofer ISE, 2013 \\
\hline & 2015 & $\begin{array}{l}\text { Pathways for Transforming the German Energy } \\
\text { System by } 2050\end{array}$ & DE, EN & 9 & 2050 & Fraunhofer ISE, 2015 \\
\hline Hansen et al. & 2019 & $\begin{array}{l}\text { Full energy system transition toward } 100 \% \\
\text { renewable energy in Germany in } 2050\end{array}$ & EN & 8 & 2050 & Hansen et al., 2019 \\
\hline
\end{tabular}

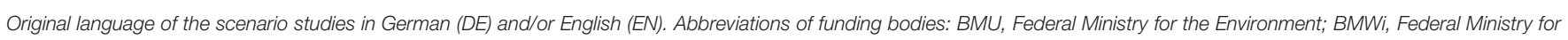

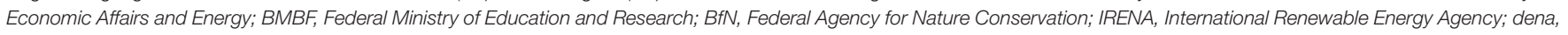

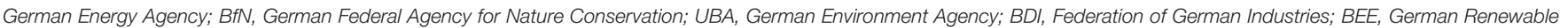

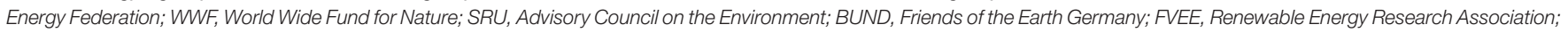
PIK, Potsdam Institute for Climate Impact Research; Fraunhofer ISE, Fraunhofer Institute for Solar Energy Systems.

to other biomass-based NETs (i.e., afforestation/reforestation, biochar, soil carbon sequestration, and ecosystem restoration) were collected.

\section{RESULTS AND DISCUSSION}

\section{Publication Trends in German Energy and Decarbonization Scenarios}

After the thorough scenario study collection and selection according to the criteria set out in the previous section, 66 relevant studies were identified, published in the years from 2002 to 2019 and containing a total of 189 scenarios. Interest in scenario studies started to increase notably around 2010, doubling in numbers until 2015 and tripling until today (Figure 2). Given the studies' time horizons, three different waves of studies can be identified: Those addressing the year 2020 leveled out after 2010. A similar dynamic can be observed right now for scenarios running up to 2030. This confirms that scenarios serve long-term planning purposes, with more than 1015 years lead time. The third observable pattern is a rapid increase of studies addressing mid-century with scenarios running up to 2050. This is also in line with the time horizons of most global assessments, including the IPCC SR1.5 report that highlights that carbon neutrality should be achieved around this time for a $1.5^{\circ} \mathrm{C}$ consistent pathway (IPCC., 2018).

When looking at the source of funding for the 66 analyzed studies, the results reveal that the majority of funding bodies are ministries or governmental agencies, representing $52 \%$ of the study sample. An additional $26 \%$ comes from industry bodies and companies. Non-governmental organizations (NGOs), think tanks and foundations funded around 12\% of the studies and research institutions another $11 \%$. The large share of funding from the political realm and industry confirms their interest in scenarios as a tool for assessing long-term policy options and measures. Therefore, the scenarios should be as technology-open as possible and not confined to a specific sub-set of technologies. As part of a broader climate change mitigation portfolio, $\mathrm{BCO}_{2}$ concepts should be assessed from a systems and scenario perspective first, before ultimately deciding on desired futures and technologies.

\section{Unbalanced Representation of Energetic and Material Use of Biomass}

Bioenergy is contributing to fossil fuel replacement, potentially achieving zero to near-zero emissions in the areas of its application. This is due to its carbon intake during plant 


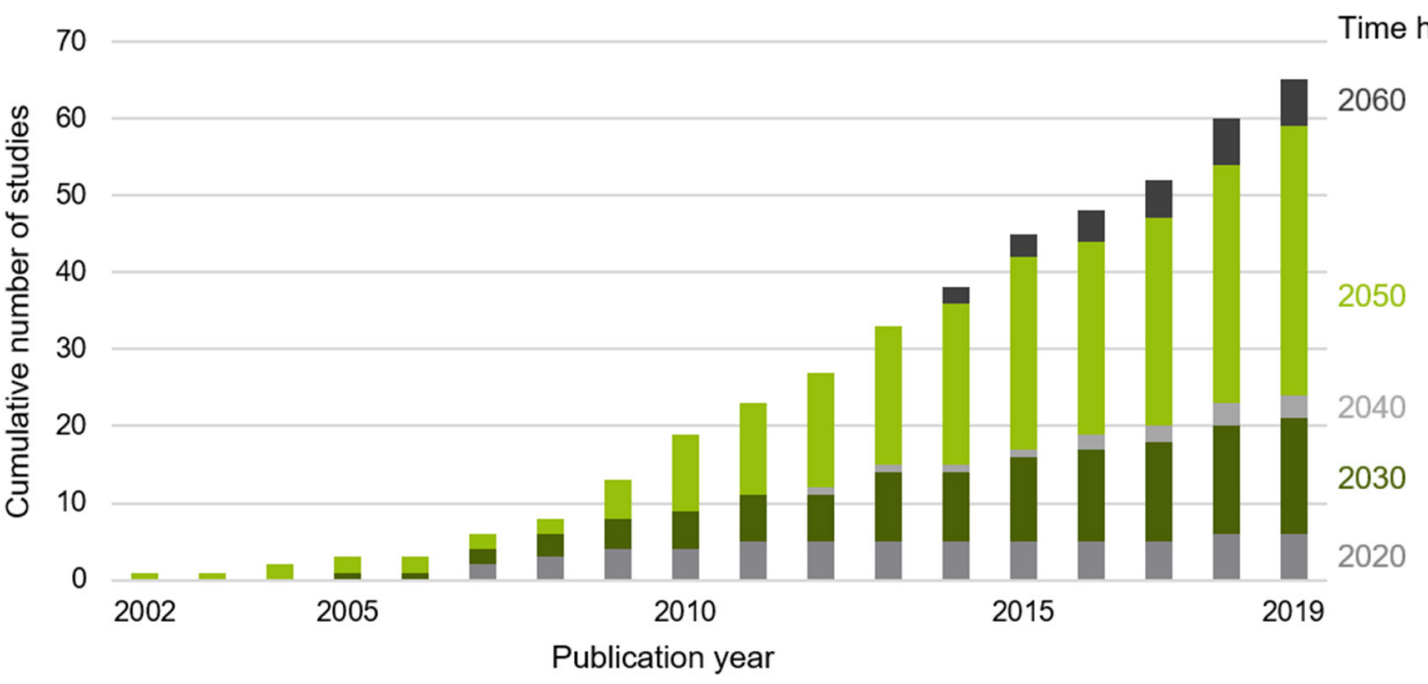

FIGURE 2 | Publication dynamics of German scenario studies for different time horizons.

growth i.e., $\mathrm{CO}_{2}$ capture from the atmosphere through photosynthesis. In contrast, biomass from a material use perspective contributes to emission reductions by substituting either fossil fuel-based products (e.g., cotton products instead of polyester) or otherwise energy-intensive products (e.g., wooden building materials instead of concrete or steel). In both cases, bioenergy's potential to offset emissions compared to fossil fuels has to be determined via a full life-cycle analysis (LCA) (Cherubini and Strømman, 2011).

Regarding the scenario coverage of biomass for energetic and material use, all 66 studies deal to some extent with bioenergy in their scenarios. As such, it is the only $\mathrm{BCO}_{2}$ category that is addressed-and most often also quantifiedin terms of GHG emission reductions within all the scenarios. In contrast, the consideration of non-energy related biomass use is scarce: only 13 out of the 66 studies mention at least once the material use dimension. This picture of unbalanced biomass use representation in the scenarios is further confirmed when assessing the biomass potentials allocated to energetic and material purposes.

With respect to domestic bioenergy potentials, only every third study $(n=24)$ provides data, resulting in a range of 216-2,300 PJ (Figure 3). This discrepancy by the factor 10 is due to the fact that there is no common methodology for determining either the underlying biomass potential or its attribution to the energy sector. For instance, dating back to the year 2004, a scenario study financed by the Federal Ministry for the Environment (BMU) assessed from a nature conservation point-of-view the land availability for bioenergy crops as well as various biomass waste and residue streams, resulting in a sustainable bioenergy potential of 1,440 PJ (BMU, 2004). Another eight scenario studies subsequently used this publication as basis for their modeling. However, despite this joint reference point, the stated potentials differ due to further assumptions made by the studies individually. On the lower end of the spectrum, studies only rely on biogenic waste and residues as bioenergy carriers, explicitly excluding dedicated energy crops due to sustainability concerns. Taking an even more conservative approach, a study commissioned by the German Environment Agency (UBA) study further divides the biogenic waste and residues by setting aside solid ones, such as straw and scrap wood, for material use, thus reducing the available biomass for energetic purposes even further (UBA, 2010). In contrast, the upper end of the spectrum consists of studies that do not provide any further information as to how their bioenergy potential is composed.

Detailed information about the material use of biomass is even less abundant. Besides the already cited UBA study, only five other studies reserve some biomass for nonenergetic purposes, either by limiting the available land for bioenergy production to account for the material supply (BMU, 2015a; BMWi, 2018), by using industrial waste streams directly for industrial products and processes (UBA, 2019b), or by not fully exploiting the technical bioenergy potential, thus leaving a certain share to material use options (BMWi, 2014, 2015).

Biomass imports can extend the available resource base, alleviating to some extent the competition for limited biomass resources. However, the question of imports causes a clear divide within the scenario studies: without stating explicit concerns, a group of eight studies allows imports to supplement the domestic resource availability, in some cases to an extent of up to $900 \mathrm{PJ}$ (BMU, 2014). In contrast, another 16 studies explicitly exclude biomass imports from their scope to avoid direct and/or indirect land use changes abroad that are likely to aggravate food security issues in emerging and developing countries (BMU, 2010, 2012). In addition, they argue that countries with climate mitigation efforts similar to the ones in Germany will tap their own biomass resources, so that relying on imports is not a sustained option in the long term (BMU, 2012). 


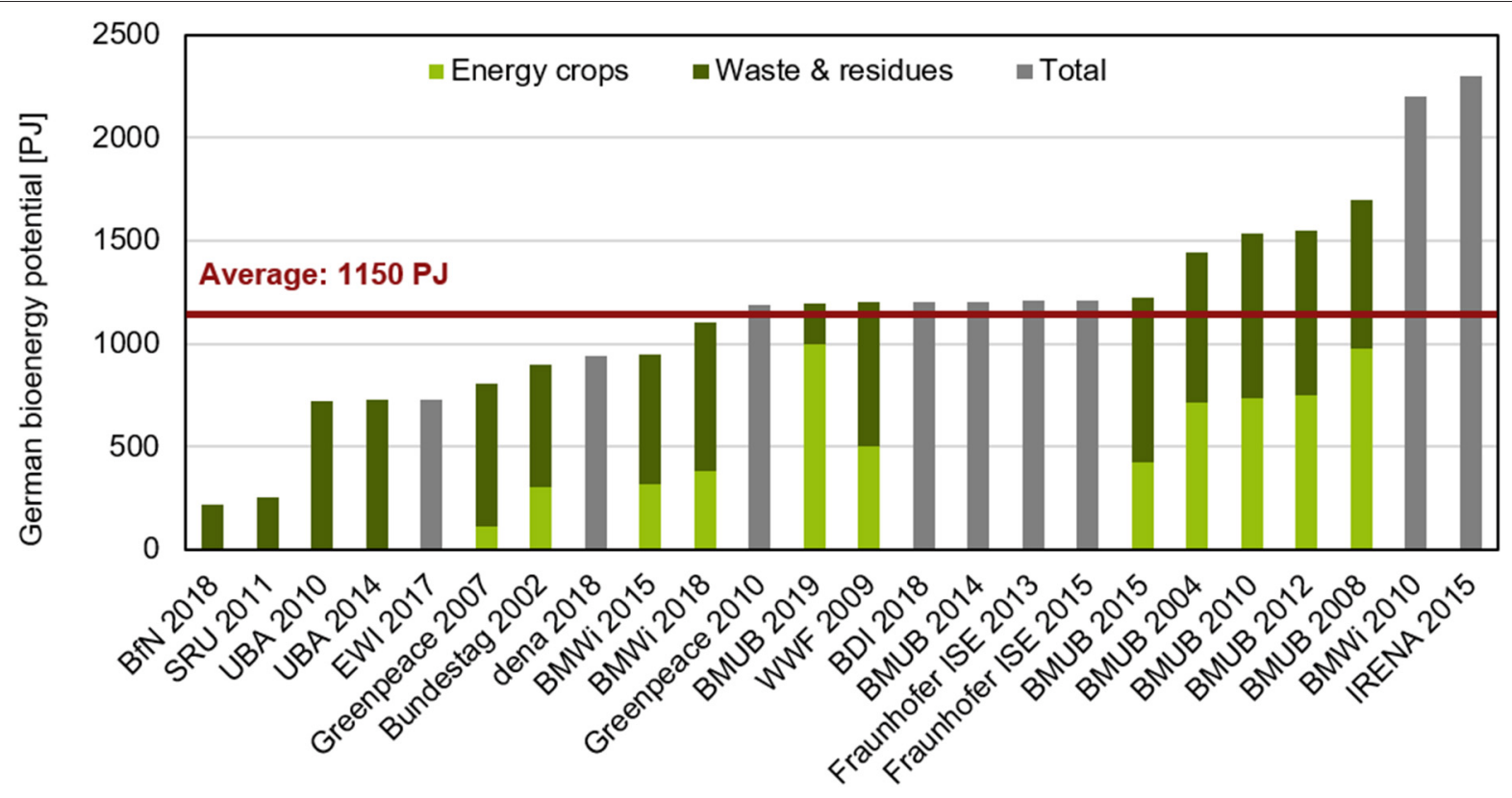

FIGURE 3 | Range of domestic bioenergy potentials as indicated by German scenario studies.

\section{Challenges in Matching Biogenic and Industrial $\mathrm{CO}_{2}$ Supply and Demand}

Similar to biomass that faces the challenge of reconciling various demands with the existing, limited potential, biogenic $\mathrm{CO}_{2}$ is also subject to supply and demand dynamics. On the supply side, biogas upgrading, bioethanol plants, and biomass-to-liquid processes yield relatively pure $\mathrm{CO}_{2}$ side-streams. $\mathrm{CO}_{2}$ capture is also possible in combination with biomass gasification or combustion but comes with a higher energy and efficiency penalty due to a lower $\mathrm{CO}_{2}$ concentration in their exhaust gases. Further adding to the equation, $\mathrm{CO}_{2}$ supply is not only possible through biogenic sources but also captured from fossil-based power stations, industrial plants, and/or directly from the air. However, fossil $\mathrm{CO}_{2}$ sources will not be further discussed in this paper, given that all analyzed studies that deal with carbon capture and utilization (CCU) options exclude fossil sources for $\mathrm{CO}_{2}$ supply. Besides the already mentioned energy penalties, the main reason for this exclusion is linked to carbon accounting issues, as fossil-based CCU only delays net $\mathrm{CO}_{2}$ being released into the atmosphere. On the demand side, $\mathrm{CO}_{2}$ can be an input for various CCU pathways that are further described below.

With regard to potential biogenic $\mathrm{CO}_{2}$ supply volumes, only few scenario studies provide data for the German case. For 2050, estimates suggest an availability of 5.3-11 $\mathrm{Mt} \mathrm{CO}_{2}$ from biogas upgrading plants (BMU, 2012; UBA, 2014). Biofuel production may lead to $36 \mathrm{Mt} \mathrm{CO}_{2}$ as side product (WWF, 2009). Other conservative figures indicate a maximum potential of 15-25 Mt $\mathrm{CO}_{2}$ from biogas upgrading, bioethanol production, and stationary bioenergy use combined (UBA, 2014; BMWi, 2018). Based on these studies, the theoretical availability of biogenic $\mathrm{CO}_{2}$ will likely range between 15 and $36 \mathrm{Mt}$. Assuming 90\% $\mathrm{CO}_{2}$ capture rates from bioenergy plants (WWF, 2009), the technical availability is slightly lower. In addition, due to the remote and dispersed location of some of these plants, only up to $70 \%$ of this technical potential might be achievable (BMU, 2012). While these figures give a first appraisal of future biogenic $\mathrm{CO}_{2}$ availability, data is sparse and related assumptions are either not stated at all or not in a transparent manner. Therefore, a robust evaluation and comparison of the biogenic $\mathrm{CO}_{2}$ sources and supply volumes cannot be performed. For instance, biogenic $\mathrm{CO}_{2}$ supply is heavily dependent on the assumed biomass potential as well as the biomass allocation within the energy sector. When prioritized as fuel for mobile consumption in the transport sector, a $\mathrm{CO}_{2}$ fraction can be recovered in the biofuel production but not in its end-use application.

Industrial point sources are an alternative $\mathrm{CO}_{2}$ source. In contrast to biogenic $\mathrm{CO}_{2}$, the captured $\mathrm{CO}_{2}$ from industrial processes is not GHG neutral. However, if $\mathrm{CO}_{2}$ emissions are inherent to a given process and therefore unavoidable, for instance in the limestone calcination process, capturing this $\mathrm{CO}_{2}$ for subsequent use or storage is still the best option for climate change mitigation. In integrated steel mills, $\mathrm{CO}_{2}$ emissions mainly occur from iron production in the blast furnace, but also in the coke production step as well as in the sinter plant when preparing the iron ore. For 2050, conservative estimates suggest an availability of $13.8 \mathrm{Mt} \mathrm{CO}_{2}$ from industrial processes, notably but not exclusively within lime and cement production (UBA, 2014). Another study indicates that steel production alone could deliver $31 \mathrm{Mt} \mathrm{CO}_{2}$ in Germany (BMU, 2012). The highest estimate of $93 \mathrm{Mt} \mathrm{CO}_{2}$ from industrial point sources extends the scope to $\mathrm{CO}_{2}$ capture in steel, ammonia, and cement production, as well as refineries and waste incineration (BDI, 2018). As these ballpark figures show, the scope of industries considered for carbon capture strongly influences the potential 


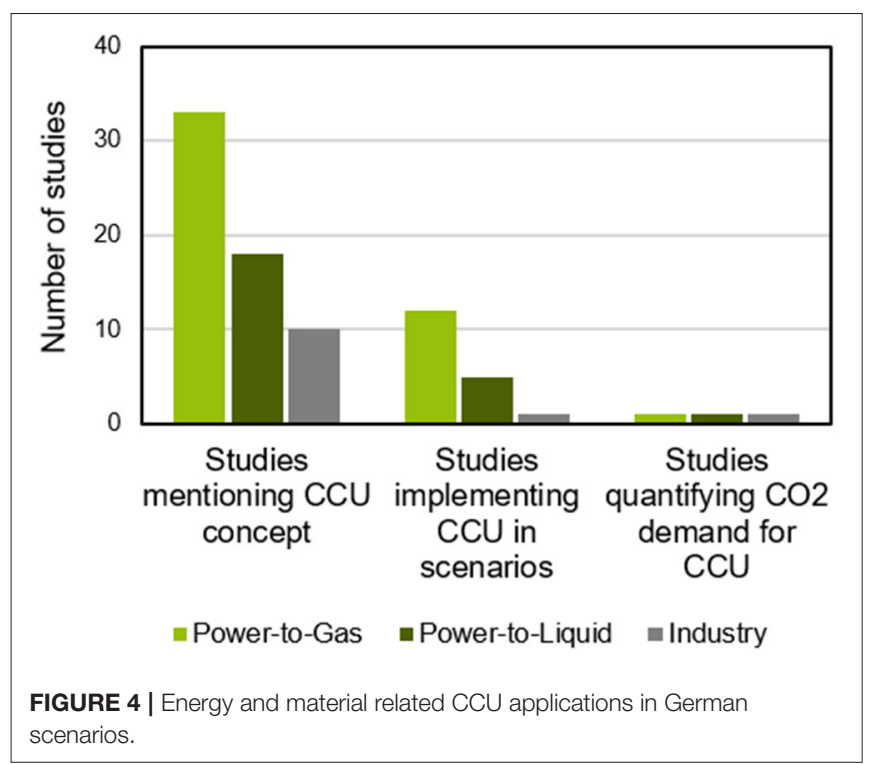

for industrial $\mathrm{CO}_{2}$ supply. In addition, depending on alternative decarbonization options for the industry sector, the residual emissions and thus the capture volume might differ. According to the official German emission reporting to UNFCCC, $\mathrm{CO}_{2}$ emissions of the entire industry sector amounted to $181 \mathrm{Mt}$ $\mathrm{CO}_{2}$ in 2017, out of which $56 \mathrm{Mt} \mathrm{CO}_{2}$ were caused by the iron and steel industry (UBA, 2019b). However, it has to be noted that these official numbers represent both process and energy-related $\mathrm{CO}_{2}$ emissions and can therefore not be directly compared to the above mentioned scenario estimates on $\mathrm{CO}_{2}$ capture from industrial processes. To avoid blast furnace emissions in the steel production, a hydrogen-based direct reduction plant and subsequent melting of the iron ore in an electric arc furnace could replace the blast furnace conversion route (UBA, 2019a). This would drastically reduce the emissions of the steel sector, thus also reducing the amount of $\mathrm{CO}_{2}$ available for capture, utilization and/or storage. However, the $\mathrm{CO}_{2}$ avoidance costs for this method amount to around $€ 490 / \mathrm{t}$ $\mathrm{CO}_{2}$ eq, which is significantly more expensive than $\mathrm{CO}_{2}$ capture combined with either utilization or storage (BDI, 2018). Another uncertainty factor lies in the capture efficiency due to multiple emission streams in some industry sectors. Taking again the steel example, while the blast furnace is the biggest emitter, there are other emission sources in the steel production, namely the coke plant and the sinter plant (BDI, 2018), rendering the implementation of carbon capture more difficult and-with lower $\mathrm{CO}_{2}$ concentrations in these plants-also more expensive, in both cost and energy use.

In contrast to limited biogenic and industrial $\mathrm{CO}_{2}$ sources, direct air capture (DAC) can theoretically deliver an unlimited amount of $\mathrm{CO}_{2}$ captured from the atmosphere. However, none of the studies considers this technology in their mitigation portfolios. The main reasons for excluding it from their assessment are prohibitively high costs and low efficiency rates due to high energy demand (UBA, 2014; BUND, 2015; dena,
2018), especially if renewables are not yet predominant in the energy mix. Nevertheless, DAC is seen as a long-term option in Germany when there is no more untapped potential from biogenic and industrial sources (BMWi, 2018). Interestingly, some studies suggest that direct air capture is more likely to be applied abroad. Assuming that countries with more favorable conditions for renewable energies, i.e., higher solar radiation and/or wind availability than in Germany, would produce synthetic fuels for international export, these countries would incur a considerable need for $\mathrm{CO}_{2}$ to convert the hydrogen produced from renewable electricity to hydrocarbon fuels. With biogenic and/or industrial $\mathrm{CO}_{2}$ sources not necessarily being colocated with the fuel production sites, these countries would rely on DAC to satisfy the $\mathrm{CO}_{2}$ demand (UBA, 2014, 2019b; BDI, 2018).

The reference to synthetic hydrocarbon fuels leads to the question of $\mathrm{CO}_{2}$ utilization options. $\mathrm{CO}_{2}$ can be put to use for both energetic and material purposes. As such, $\mathrm{CO}_{2}$, along with hydrogen, is a building block for platform chemicals, plastics, and synthetic hydrocarbon fuels. Since the production of hydrogen through water electrolysis requires large quantities of electricity, these CCU pathways are also labeled as Powerto-X, whereas $\mathrm{X}$ can stand for gas (PtG), liquid fuels (PtL), chemicals $(\mathrm{PtC})$, or other applications. As Figure 4 shows, none of these $\mathrm{CO}_{2}$ utilization concepts are adequately represented within the German scenario studies. Industry CCU, i.e., using $\mathrm{CO}_{2}$ as a feedstock for industrial processes and products (e.g., input for platform chemicals; use as refrigerant gas, solvent, dry ice etc.), is the least mentioned concept. Moreover, only three studies incorporate syngas-based CCU routes it into their assessments which allow to subsequently build-up all major platform chemicals (UBA, 2014, 2019a; dena, 2018). In the long-term, the potential for $\mathrm{CO}_{2}$ utilization as feedstock in the industrial realm in Germany is estimated by one scenario study to be limited to $5 \mathrm{Mt}$ per year in addition to its current use (dena, 2018). In contrast, the energetic use of $\mathrm{CO}_{2}$ is better represented, with PtG being part of the scenario modeling in about $30 \%$ of the studies. However, this $\mathrm{PtG}$ - and to a lesser extent PtLintegration is not primarily motivated by the prospects of $\mathrm{CO}_{2}$ utilization. In fact, only two studies explicitly indicate the amount of $\mathrm{CO}_{2}$ needed, namely $27 \mathrm{Mt}$ for synthetic methane production in one case (UBA, 2014) and $79 \mathrm{Mt}$ for the production of methanol and dimethyl ether in another case (Hansen et al., 2019). Instead the focus with regard to PtG and PtL lies on their ability to (a) function as temporary storage of excess power from variable renewable energy sources, and (b) provide a renewable energy source for the otherwise difficult to decarbonize sectors, such as aviation and heavy duty trucks. The latter reason is also why various studies consider importing synthetic energy carriers, sometimes even up to $85-100 \%$ of the entire projected PtG or PtL consumption (BDI, 2018; BMU, 2019; UBA, 2019b). Shortcomings in CCU scenario modeling therefore are the lack of transparent assumptions and quantified data on $\mathrm{CO}_{2}$ as major input sources for $\mathrm{PtX}$, both from an energy and even more importantly a material use perspective. As a consequence, a matching of domestically available $\mathrm{CO}_{2}$ supply with the potential $\mathrm{CO}_{2}$ demand is not possible. 


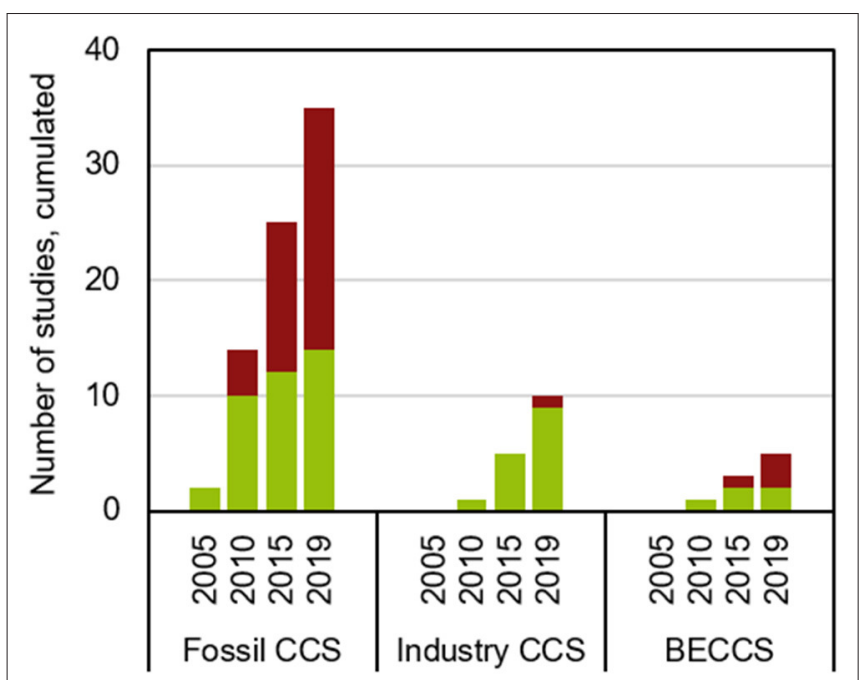

- Studies that explicitely exclude CCS - Studies that take CCS into account

FIGURE 5 | The exclusion of fossil, industrial and biomass-based CCS in German scenario studies over time.

\section{Costs vs. Public Acceptance: Rationales for and Against (BE)CCS}

While BECCS is implemented in almost all IAMs and therefore well-represented in global IPCC scenarios (Forster et al., 2018), the results for the German scenario landscape are much different. Figure 5 shows that BECCS was included in a scenario study for the first time around 2010. In this pioneering study, the modeling framework provided a CCS option for bioethanol and biodiesel production, leading to a scenario of capturing $32 \mathrm{Mt}$ $\mathrm{CO}_{2}$ from biogenic origin in 2050 (WWF, 2009). Within the last 10 years, however, only one further study has assessed and quantified BECCS. Extending the scope to cover both biogas and bioethanol plants (but excluding biodiesel production), the calculations only resulted in $8.5 \mathrm{Mt} \mathrm{CO}_{2}$ captured and stored (BMU, 2014). Nevertheless, the number of studies that explicitly exclude BECCS also remained relatively low: only three studies deliberately decided against this technology option due to (a) general skepticism about CCS (BUND, 2015), (b) various environmental reasons (UBA, 2019b), and (c) a prioritization of biomass for the industrial sector, leaving only a small biomass share to the energy sector so that large-scale BECCS solutions wouldn't be feasible (BDI, 2018).

CCS as mitigation option for coal or natural gas fired power stations was largely accepted and implemented until around 2010 but highly disputed afterwards (Figure 5). This strong opposition to fossil CCS might have negatively affected the perception toward CCS in general, causing more precaution as to the adoption of industrial or biomass-based CCS in German modeling frameworks. In fact, although first addressed in 2009, the intensified discussion of industrial CCS is a more recent development in Germany. The initial assumptions for CCS in the industry sector were very simplistic with unrealistic capture rates of $100 \%$ across all sub-sectors. This resulted in a first estimate of 37-53 $\mathrm{Mt} \mathrm{CO}_{2}$ sequestered from industrial point sources in 2050 (WWF, 2009). Despite more sophisticated calculation methods in the latest scenarios with industry CCS, the range of modeling results is still in the same order of magnitude with 16-93 Mt $\mathrm{CO}_{2}$ (BMU, 2015a; BDI, 2018; BMWi, 2018; dena, 2018). The uncertainties already mentioned in section Challenges in Matching Biogenic and Industrial $\mathrm{CO}_{2}$ Supply and Demand with respect to $\mathrm{CO}_{2}$ availability from industrial sources apply here as well. Interestingly though, the depiction of industry CCS is mainly positively connoted as final resort for achieving carbon neutrality in the industrial sectors. However, despite its uncontested asset of creating negative emissions, BECCS did not mirror a similar dynamic in recent years.

The limited number of deliberate representation of BECCSor CCS in general-is likely to be a result of various obstacles that scenario studies perceive in matters of CCS deployment (Table 2). Thirty out of the 66 analyzed studies raised at least one area of concern that either limited or prohibited CCS implementation in their scenarios. Over the entire assessment period from 2002 to 2019, technology-related items were the most prevalent. While techno-economic uncertainties such as the maturity and availability of capture technologies were more of a concern in the late 2000s, reservations are nowadays rather express with regard to the overall process efficiency and the energy penalty associated with the $\mathrm{CO}_{2}$ capture. Within the category of economic arguments, studies are most critical about investment costs and risks on both plant scale and overall infrastructure. Generalized and often not further specified long-term risks for the environment are noted in every third scenario study. While storage capacity and competition for storage space and/or locations is in 8 studies an area of concern, the systems perspective of integrating CCS activities is less of a preoccupation.

As already mentioned, the frequency of these arguments, cumulated over time, points toward an early, and sustained preoccupation with techno-economic concerns (Figure 6). However, in parallel, a first sign of public awareness issues arises with the introduction of the EU CCS directive and its subsequent implementation in Germany. Similarly, in the postParis Agreement debate on decarbonization options, negative perceptions regarding public acceptance of CCS resurfaced in the scenarios. Interestingly, although none of the scenario studies provides evidence for the supposed societal non-acceptance, this arguments is the single most raised rationale against CCS. A study commissioned by the Federation of German Industries (BDI) partially attenuates this narrative: If there are no or only much more expensive alternatives to industrial CCS, both political and social acceptance is assumed (BDI, 2018). Insofar, public perception would only be a question of costs. Slightly more nuanced, the German Energy Agency (dena) approves CCS as last resort in spite of societal concern-but only if even more costly alternatives are already exploited (dena, 2018). The latest study sponsored by the Federal Ministry for Economic Affairs and Energy (BMWi) assumes that public acceptance is only a minor obstacle for CCS in the industrial sector due to the lack 
TABLE 2 | Obstacles to (BE)CCS deployment mentioned in German scenarios $(n=30)$.

\begin{tabular}{|c|c|c|c|}
\hline \multicolumn{2}{|c|}{$\begin{array}{l}\text { Main category } \\
\text { [number of studies addressing at least one subcategory] }\end{array}$} & \multicolumn{2}{|l|}{$\begin{array}{l}\text { Sub-category } \\
\text { [number of studies per item] }\end{array}$} \\
\hline \multirow[t]{3}{*}{ Technology } & 19 & Techno-economic uncertainties & 13 \\
\hline & & Energy and efficiency penalty & 12 \\
\hline & & Missing upscaling experience & 4 \\
\hline \multirow[t]{3}{*}{ Economy } & 18 & Investment risks and operational costs & 12 \\
\hline & & Insufficient market penetration & 6 \\
\hline & & Economic viability & 4 \\
\hline \multirow[t]{3}{*}{ Policy and Society } & 17 & Lack of public acceptance & 14 \\
\hline & & Legal/regulatory concerns & 9 \\
\hline & & Interdiction of $\mathrm{CO}_{2}$ export for storage & 2 \\
\hline \multirow[t]{4}{*}{ Environment } & 13 & Unknown long-term risks for the environment & 10 \\
\hline & & $\mathrm{CO}_{2}$ leakage (e.g., ground water pollution) & 8 \\
\hline & & Security/ health concerns (e.g., accidents, explosion) & 5 \\
\hline & & Transport infrastructure as threat to natural landscapes & 2 \\
\hline \multirow[t]{3}{*}{ Storage capacity } & 11 & Limited geological storage capacity & 8 \\
\hline & & Competition for storage: CCS vs. Geothermal energy & 7 \\
\hline & & Competition for storage: fossil vs. biogenic vs. industrial $\mathrm{CO}_{2}$ & 2 \\
\hline \multirow[t]{2}{*}{ Systems perspective } & 6 & No CCS in power sector/other decarbonization options exist & 4 \\
\hline & & Complex infrastructure changes necessary for CCS integration & 3 \\
\hline
\end{tabular}

of cost-effective alternatives (BMWi, 2018). However, all of the recent publications supported by ministries, agencies or NGOs related to environmental matters or nature conservation either do not address or explicitly exclude CCS (BUND, 2015; BfN, 2018; BMU, 2019; UBA, 2019b). This being said, the political context of the CCS debate is likely to change with German Chancellor Angela Merkel putting the CCS debate back on the table in May 2019, veering away from the fossil CCS rhetoric to a focus on delivering the Paris Agreement (Bundeskanzleramt, 2019; Kornelius et al., 2019). These contrasting views suggest that the public acceptance argument is seemingly more a political one than a primarily societal one. This is further underpinned by the fact that there are also societal objections to and citizen initiatives against onshore wind parks (Reusswig et al., 2016; Langer et al., 2018), geothermal energy systems (Kunze and Hertel, 2017; Benighaus and Bleicher, 2019), or the extension of the transmission grid (Neukirch, 2016; Kühne and Weber, 2017). However, this does not prevent these options from being part of the future energy mix.

\section{Other Biomass-Based NETs: Conserving Ecosystem Services}

Besides BECCS, large-scale afforestation is the second most prominently featured NET option in numerous global IAMs such as AIM, GCAM, and MESSAGE-GLOBIOM (Forster et al., 2018). However, this is not the case in the present selection of scenario studies for Germany, at least not when it comes to largescale implementation. For example, the word "afforestation" appears explicitly in only five studies, among which only a single analysis provides an estimation of the associated GHG emission reduction, namely an annual $18 \mathrm{t} \mathrm{CO}_{2}$ per hectare when converting pastureland into forests (UBA, 2014). In addition, however, various studies mention measures to preserve at least the existing net carbon sink function of forests (WWF, 2009; BMU, 2019). These include, for example, some reserved areas for natural forest development as well as the implementation of sustainable forest management practices in the public forests (Greenpeace, 2015). In addition, arable land and grassland are partially converted into forest (BMU, 2015a, 2017).

Within the analyzed scenarios, the category of wetlands and ecosystem restoration follows a similar logic: no large-scale negative emissions initiatives, but individual measures to keep the land use, land use change and forestry (LULUCF) overall as a natural sink. In the scenarios, it is common practice to stop peat extraction on the one hand and to rewet peat soils on the other (UBA, 2014, 2019a,b; Greenpeace, 2015; BMU, 2019). A partial implementation of the measures can amount to a reduction of $13.3 \mathrm{Mt} \mathrm{CO}_{2}$ in 2050. Savings of up to $37.5 \mathrm{Mt} \mathrm{CO}_{2}$ are feasible if a full implementation takes place (BMU, 2015a).

In comparison, soil carbon sequestration (SCS) is rarely taken into account in the scenarios, based on the assumption that carbon uptake of agricultural soil is reversible and cannot be sustained in the longer run (UBA, 2014). Only a Greenpeace study assessed the potential of natural $\mathrm{CO}_{2}$ sequestration, e.g., through increased cultivation of humus-building plants, potentially leading to a moderate $\mathrm{GHG}$ reduction of $3.8 \mathrm{Mt} \mathrm{CO}_{2}$ in 2050 (Greenpeace, 2015). Information available for biochar is even less abundant, having only been mentioned once in a single study. Hence, these NET options are largely non-existent in the German decarbonization scenarios.

Beyond the different depths in which the respective NETs categories are represented in the scenarios, a common trend can 


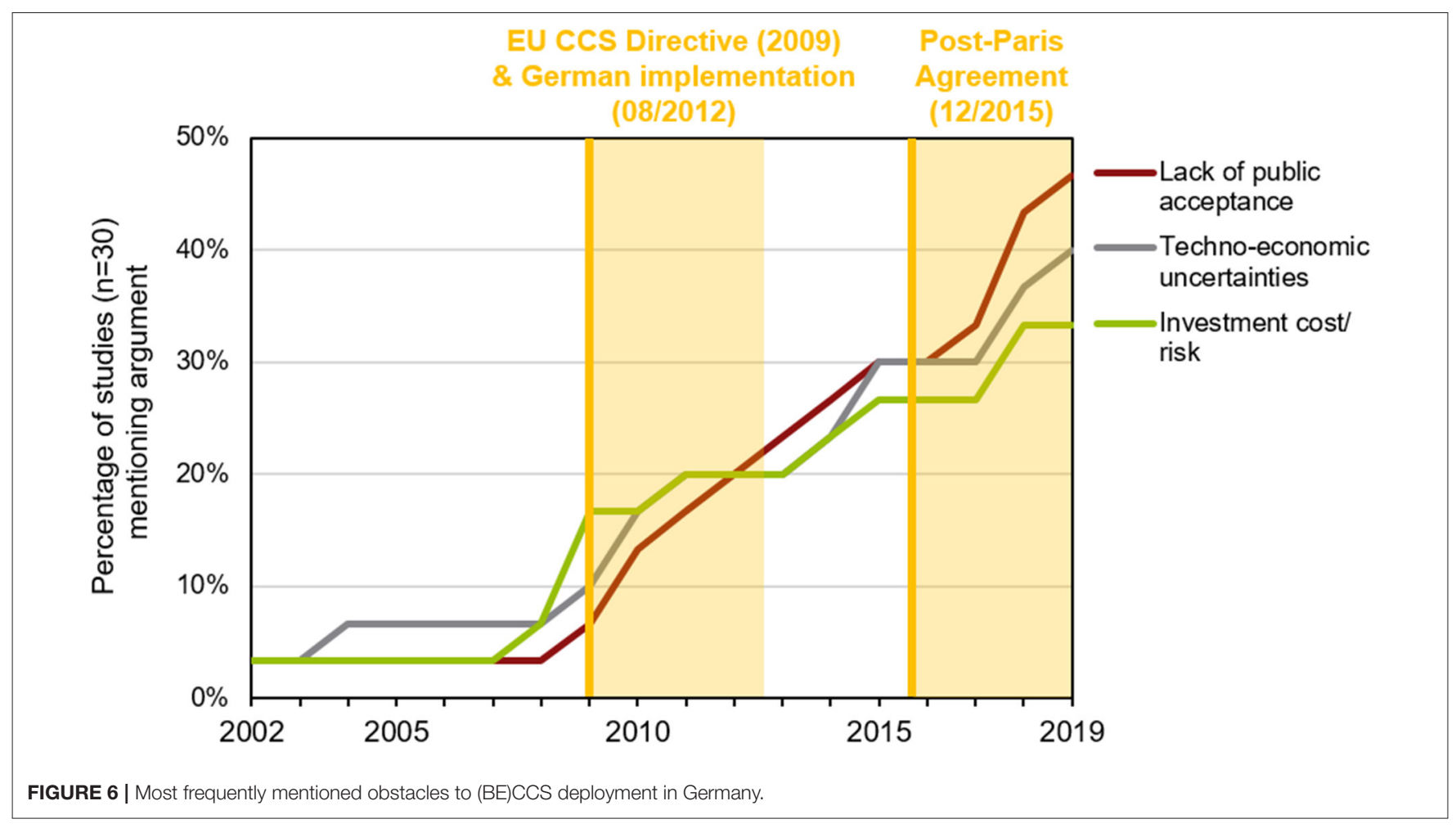

nevertheless be identified: without exception, all scenario studies that provide more detailed assumptions and/or quantification of emission savings for the biomass-based NETs and the LULUCF sector in general have been financed by environmental ministries, agencies and NGOs. Other branches of government or industry are mostly limited to integrated energy system models for electricity, heat, and transport. However, in view of an economy-wide approach and to better reflect non-energy related emissions, the integration should more systematically extend to the LULUCF sector.

\section{Moving From $\mathrm{BCO}_{2}$ Blind Spots to an Overarching Scenario Framework}

Revisiting the classification of $\mathrm{BCO}_{2}$ concepts as set out in Figure 1, and contrasting it with the previous findings on each of the $\mathrm{BCO}_{2}$ categories, there is only one bright spot: the energetic use of bio-resources. While this does not come as a surprise for the traditional bioenergy sector thanks to the longstanding tradition of biomass as energy carrier, the relatively strong representation of (biogenic) $\mathrm{CO}_{2}$ utilization is, however, a rather new phenomenon. This can mainly be attributed to the ever growing role of sector coupling in Germany, necessitating besides hydrogen also a carbon source. Regarding bioenergy in combination with CCS, many studies rejected CCS so far based on the grounds of a diffuse and not evidence-based assumption of societal and political nonacceptance. However, the analysis has also shown that this is not set in stone, at least for industrial CCS. In this respect, BECCS could possibly also become an accepted or at least tolerated option in the medium to long term, in particular thanks to its unique selling point of sustainable energy production with simultaneous generation of negative emissions. To strengthen the representation of biomass for energetic use, including BECCS, in future scenarios, the underlying assumptions for biomass resource types, potentials and international trade should be documented more transparently as they heavily affect all subsequent decisions on the allocation of biomass to different sectors and ultimately also the amount of GHG emissions savings that can come from biomass use. In this regard, GHG emission accounting along the bioenergy lifecycle should be given greater attention in the scenario studies, notably but not limited to direct and indirect land use change effects in developing and emerging countries. In addition, biomass allocation needs to be put in a systems perspective, especially if BECCS is to play a role in the future energy system as it requires more large-scale and centralized bioenergy plants.

The competition for biomass resources extends to the material-related $\mathrm{BCO}_{2}$ concepts. The analysis revealed that quantitative assessment of both biomass and biogenic $\mathrm{CO}_{2}$ for material applications are mostly non-existent. Furthermore, if the concept of material use is qualitatively mentioned, this is solely done as a means to illustrate examples rather than for taking a holistic and structured approach to analyzing biomass use for all non-energetic purposes. Leaving significant room for improvement, the introduction of material flow analyses within the scenario frameworks could be instrumental in assessing these competing biomass uses, identify opportunities for cascading use strategies, and ultimately guide biomass allocation. This also constitutes a first step into an integrated bioeconomy thinking, i.e., "the knowledge-based production and use of renewable 
resources, in order to provide products, processes and services in all areas of the economy, within the framework of an economic system that is viable for the future" (BMEL, 2014).

While energy and decarbonization scenario studies that were published within the last 10-15 years only scratched upon the surface of biomass-based NETs so far, modeling, and monitoring their carbon sink capacity and performance is a prerequisite for determining an acceptable amount of residual emissions in other sectors without compromising overall climate neutrality by the mid-century. However, this implies that competition for different land use options will increase as some of the land-based NETs are mutually exclusive. Therefore, it will be crucial to bridge the gap between energy and land use models in order to build an adequate framework for the integration of biomass-based NETs into German decarbonization scenarios.

\section{CONCLUSION}

This paper set out to explore the technology-openness of energy and decarbonization scenarios with respect to biomass-based carbon removal concepts $\left(\mathrm{BCO}_{2}\right)$. By performing a systematic review of 66 studies containing a total of 189 scenarios for Germany, the aim was to provide a first appraisal of the representation of $\mathrm{BCO}_{2}$ in a scenario context and to formulate recommendations for their better integration into existing and future modeling frameworks.

Our findings indicate that bioenergy is the best-represented $\mathrm{BCO}_{2}$ concept, however assumptions made for bioenergy potentials either take outdated references as assessment basis or are not detailed enough with regard to biomass resource types and GHG emission accounting. In contrast, the material biomass use perspective is largely not addressed, especially lacking quantified data. The challenge with biogenic $\mathrm{CO}_{2}$ is to match its supply and demand, also in the light of other potential $\mathrm{CO}_{2}$ sources from industry and direct air capture. Technoeconomic assumptions and data for BECCS is available but has only been implemented in few scenarios, mainly due to an assumption of non-existent public acceptance. A critical review however suggests to revisit the public acceptance argument as scenario studies failed to provide evidence for their claim. Other NETs have-if at all-not been addressed under a largescale negative emissions perspective but rather as conservation measure for its current carbon sink function.

\section{REFERENCES}

50Hertz (2016). Energiewende Outlook 2035: Entwicklungspfade der Energiewende und deren Folgen. Abschlussbericht. Available online at: http://www. 50hertz.com/Portals/1/Dokumente/Netz/Netzentwicklung/Downloadbox \%20Energiewende\%20Outlook\%202035/Abschlussbericht.pdf (accessed July 01, 2019).

Agora (2013). Kostenoptimaler Ausbau der Erneuerbaren Energien in Deutschland: Ein Vergleich möglicher Strategien für den Ausbau von Wind- und Solarenergie in Deutschland bis 2033. Available online at: http://www.agora-energiewende. de/fileadmin2/Projekte/2012/Kostenoptmaler-Ausbau-EE/Agora_Studie_ Kostenoptimaler_Ausbau_der_EE_Web_optimiert.pdf (accessed June 12, 2019).
Acknowledging that the aim of scenario modeling is not to replicate the reality but to explore different technology options and their interdependencies, the findings of this study indicate two major axes of improvement, namely the need for integrated energy-land modeling frameworks as well as the adoption of bioeconomy perspectives in the scenario narrative. This being said, extending the modeling scope increases complexity and creates trade-offs with regard to granularity. To tackle these challenges, soft-linking otherwise separate models could be envisaged. This allows in an iterative process to converge on key parameters instead of requiring a full model integration. Existing global IAMs can serve as a blueprint in this regard, such as the energy supply model MESSAGE linked via an emulator to the land use model GLOBIOM. In order to facilitate such integrated energy-land modeling frameworks, interdisciplinary research, and cooperation is of crucial importance. Having shown in this study that environmental organizations from the governmental and non-governmental sphere were most likely to publish scenario studies that do include land use considerations, they could be instrumental in funding and facilitating such interactions. Finally, beyond the topic of $\mathrm{BCO}_{2}$ concepts, guidelines for standardized scenario documentations could support greater transparency and better comparability across models and scenarios.

\section{AUTHOR CONTRIBUTIONS}

$\mathrm{AH}$ devised the project with supervision by NS and DT. AH collected, analyzed, interpreted the data, and wrote the paper. All authors discussed the results and critically commented on the manuscript.

\section{FUNDING}

This research received funding from the Federal Ministry of Food and Agriculture (BMEL) pursuant to a resolution by the German Bundestag.

\section{ACKNOWLEDGMENTS}

We thank Indrani Kar for thorough proof reading and the two reviewers for their valuable comments and recommendations that helped to improve this work.

Bartholdsen, H. K., Eidens, A., Löffler, K., Seehaus, F., Wejda, F., Burandt, T., et al. (2019). Pathways for Germany's low-carbon energy transformation towards 2050. Energies 12:2988. doi: 10.3390/en12152988

BDEW, GIZ, and PwC (2016). Delphi Energy Future 2040: Delphi-Study on the Future of Energy Systems in Germany, Europe and the world by the Year 2040. Available online at Available online at: http://www.pwc.com/gx/en/energyutilities-mining/pdf/delphi-energy-future.pdf (accessed November 21, 2019).

BDI (2013). Trendstudie 2030+: Kompetenzinitiative Energie des BDI. Im Auftrag des Bundesverbandes der Deutschen Industrie BDI. Available online at: http:http://image-src.bcg.com/Images/Trendstudie\%202030_tcm108-141125. pdf (accessed April 08, 2019).

BDI (2018). Klimapfade für Deutschland. Im Auftrag des Bundesverbandes der Deutschen Industrie (BDI). Availabel online at: Available online at: 
http://www.prognos.com/uploads/tx_atwpubdb/20180118_BDI_Studie_ Klimapfade_fuer_Deutschland_01.pdf (accessed April 08, 2019).

BDI, DEBRIV, GVSt, VDN,VGB PowerTech, and VRE (2007). Energiewirtschaftliches Gesamtkonzept 2030: Szenariendokumentation. Im Auftrag des Verband der Elektrizitätswirtschaft (VDEW), gemeinsam mit den Verbänden BDI, DEBRIV, GVSt, VDN, VGB PowerTech und VRE. Available online at: http://braunkohle.de/index.php?article_id=98\&fileName=studie_ 2030_endbericht_final.pdf (accessed April 12, 2019).

BEE (2014a). Aktuelle Szenarien der deutschen Energieversorgung unter Berücksichtigung der Eckdaten des Jahres 2014. Kurzexpertise für den Bundesverband Erneuerbare Energien e.V. Available online at: http:// www.bee-ev.de/fileadmin/Publikationen/20150419-Szenarien_SZEN-15.pdf (accessed April 05, 2019).

BEE (2014b). GROKO - II: Szenarien der deutschen Energieversorgung auf der Basis des EEG-Gesetzentwurfs - insbesondere Auswirkungen auf den Wärmesektor. Kurzexpertise für den Bundesverband Erneuerbare Energien e.V. Available online at: http://www.bee-ev.de/fileadmin/Publikationen/Studien/20140827 SzenarienderdeutschenEnergieversorgung_Waermesektor.pdf (accessed July 03, 2019).

BEE (2015). Szenarien der deutschen Energieversorgung vor dem Hintergrund der Vereinbarungen der Großen Koalition. Kurzexpertise für den Bundesverband Erneuerbare Energien e.V. Available online at: http://www.bee-ev.de/ fileadmin/Publikationen/Studien/20140205_BEE-Szenarien_GROKO_Nitsch. pdf (accessed April 05, 2019).

BEE (2016). Die Energiewende nach COP 21: Aktuelle Szenarien der deutschen Energieversorgung. Kurzstudie für den Bundesverband Erneuerbare Energien e.V. Avaliable online at: Available online at: http://www.bee-ev.de/fileadmin/ Publikationen/Studien/Joachim_Nitsch_Energiewende_nach_COP21_ Langversion.pdf (accessed April 05, 2019).

BEE (2017). Erfolgreiche Energiewende nur mit verbesserter Energieeffizienz und einem klimagerechten Energiemarkt: Aktuelle Szenarien 2017 der deutschen Energieversorgung. Available online at: http://www.bee-ev.de/fileadmin/ Publikationen/Studien/Erfolgreiche_Energiewende_Szenarien_2017_Nitsch. pdf (accessed April 05, 2019).

BEE (2018). Was für einen erfolgreichen Klimaschutz erforderlich ist: Schlussfolgerungen aus aktuellen Szenarien der deutschen Energieversorgung. Available online at: http://co2abgabe.de/wp-content/uploads/2018/03/ Klimaschutz-18.pdf (accessed July 03, 2019).

Benighaus, C., and Bleicher, A. (2019). Neither risky technology nor renewable electricity: Contested frames in the development of geothermal energy in Germany. Energy Res. Soc. Sci. 47, 46-55. doi: 10.1016/j.erss.2018.08.022

$\mathrm{BfN}$ (2018). Naturverträgliche Energieversorgung aus 100\% erneuerbaren Energien: Gefördert durch das Bundesamt für Naturschutz. Avaliable online at: Available online at: http://www.bfn.de/fileadmin/BfN/service/Dokumente/ skripten/Skript501.pdf (accessed July 08, 2019).

BMEL (2014). National Policy Strategy on Bioeconomy: Renewable Resources and Biotechnological Processes as a Basis for Food, Industry and Energy. Available online at: http://www.bmel.de/SharedDocs/Downloads/EN/Publications/ NatPolicyStrategyBioeconomy.pdf?__blob=publicationFile (accessed January $16,2020)$.

BMU (2004). Ökologisch optimierter Ausbau der Nutzung erneuerbarer Energien in Deutschland: Langfassung. Studie im Auftrag des Bundesministeriums für Umwelt, Naturschutz und Reaktorsicherheit, FKZ 90141 803. Available online at: http://www.ifeu.de/landwirtschaft/pdf/Oekologisch_optimierter_Ausbau_ Langfassung.pdf (accessed June 13, 2019).

BMU (2008). Weiterentwicklung der "Ausbaustrategie Erneuerbare Energien" vor dem Hintergrund der aktuellen Klimaschutzziele Deutschlands und Europas: Leitstudie 2008. Im Auftrag des Bundesministeriums für Umwelt, Naturschutz und Reaktorsicherheit (BMU). Available online at: http://www. erneuerbare-energien.de/EE/Redaktion/DE/Downloads/Studien/leitstudie2008.pdf (accessed April 10, 2019).

BMU (2009a). Langfristszenarien und Strategien für den Ausbau erneuerbarer Energien in Deutschland: Leitszenario 2009. Im Auftrag des Bundesministeriums für Umwelt, Naturschutz und Reaktorsicherheit (BMU). Available online at: http://www.erneuerbare-energien.de/EE/Redaktion/ DE/Downloads/Studien/leitszenario-2009.pdf?_blob=publicationFile\&v=2 (accessed April 10, 2019).

BMU (2009b). Projektionsbericht 2009 gemäß Entscheidung 280/2004/EG. Available online at: http://cdr.eionet.europa.eu/de/eu/ghgpro/envsgwza/ (accessed April $16,2019)$.
BMU (2010). Langfristszenarien für den Ausbau der erneuerbaren Energien in Deutschland bei Berücksichtigung der Entwicklung in Europa und global: Leitstudie 2010. Im Auftrag des Bundesministeriums für Umwelt, Naturschutz und Reaktorsicherheit (BMU). Available online at: http://elib.dlr.de/68660/1/ EEG_Kosten_Langfristszenarien.pdf (accessed April 10, 2019).

BMU (2011). Projektionsbericht 2011 gemäß Entscheidung 280/2004/EG. Available online at: http://cdr.eionet.europa.eu/de/eu/ghgpro/envtcqp5g/ (accessed April $16,2019)$.

BMU (2012). Langfristszenarien für den Ausbau der erneuerbaren Energien in Deutschland bei Berücksichtigung der Entwicklung in Europa und global: Leitstudie 2011. Im Auftrag des Bundesministeriums für Umwelt, Naturschutz und Reaktorsicherheit (BMU). Available online at: http://www.dlr.de/dlr/ Portaldata/1/Resources/bilder/portal/portal_2012_1/leitstudie2011_bf.pdf (accessed April 10, 2019).

BMU (2013). Projektionsbericht 2013 gemäß Entscheidung 280/2004/EG. Available online at: http://cdr.eionet.europa.eu/de/eu/ghgpro/envuucoda/130313 Projektionsbericht_DE_final.doc (accessed April 16, 2019).

BMU (2014). Klimaschutzszenario 2050: 1. Modellierungsrunde. Studie im Auftrag des Bundesministeriums für Umwelt, Naturschutz, Bau und Reaktorsicherheit (BMU). Available online at: http://www.oeko.de/oekodoc/2065/2014-638-de. pdf (accessed May 28, 2019).

BMU (2015a). Klimaschutzszenario 2050: 2. Endbericht. Studie im Auftrag des Bundesministeriums für Umwelt, Naturschutz, Bau und Reaktorsicherheit (BMU). Available online at: http://www.oeko.de/oekodoc/2451/2015-608-de. pdf (accessed May 28, 2019).

BMU (2015b). Projektionsbericht 2015 gemäß Verordnung 525/2013/EU. Availabel online at: http://cdr.eionet.europa.eu/de/eu/mmr/art04-13-14_lcds_pams_ projections/envvqlq8w/150422_Projektionsbericht_2015_final.pdf (accessed April 16, 2019).

BMU (2016). Klimaschutzplan 2050: Klimaschutzpolitische Grundsätze und Ziele der Bundesregierung. Available online at: http://www.bmu.de/fileadmin/ Daten_BMU/Download_PDF/Klimaschutz/klimaschutzplan_2050_bf.pdf (accessed May 21, 2019).

BMU (2017). Projektionsbericht 2017 für Deutschland gemäß Verordnung (EU) Nr. 525/2013. Available online at: http://cdr.eionet.europa.eu/de/eu/mmr/art0413-14_lcds_pams_projections/projections/envwqc4_g/170426_PB_2017_-final.pdf (accessed April 16, 2019).

BMU (2019). Folgenabschätzung zu den ökologischen, sozialen und wirtschaftlichen Folgewirkungen der Sektorziele für 2030 des Klimaschutzplans 2050 der Bundesregierung: Studie im Auftrag des Bundesministeriums für Umwelt, Naturschutz, Bau und Reaktorsicherheit (BMU). Available online at: http:// www.oeko.de/fileadmin/oekodoc/Folgenabschaetzung-Klimaschutzplan2050-Endbericht.pdf (accessed July 04, 2019).

BMWi (2005). Energiereport IV - Die Entwicklung der Energiemärkte bis zum Jahr 2030: Energiewirtschaftliche Referenzprognose. Kurzfassung. Im Auftrag des Bundesministeriums für Wirtschaft und Arbeit (BMWi). Available online at: http://www.prognos.com/uploads/tx_atwpubdb/050400_Prognos_ EWI_Energiereport_IV.pdf (accessed April 18, 2019).

BMWi (2007). Energieszenarien für den Energiegipfel 2007: Endbericht inklusive Anhang $2 \%$-Variante. Im Auftrag des Bundesministeriums für Wirtschaft und Technologie(BMWi). Available online at: http://www.prognos.com/fileadmin/ pdf/publikationsdatenbank/Energieszenarien-fuer-den-Energiegipfel-D2007.pdf (accessed April 18, 2019).

BMWi (2010a). Die Entwicklung der Energiemärkte bis 2030: Energieprognose 2009. Available online at: ftp://ftp.zew.de/pub/zew-docs/gutachten/ Energieprognose_2009_Hauptbericht.pdf (accessed April 18, 2019).

BMWi (2010b). Energieszenarien für ein Energiekonzept der Bundesregierung: Projekt Nr. 12/10 des Bundesministeriums für Wirtschaft und Technologie (BMWi). Available online at: http://www.prognos.com/uploads/tx_atwpubdb/ 100827_Prognos_Studie_Energieszenarien_fuer_ein_energiekonzept_der_ Bundesregierung.pdf (accessed April 17, 2019).

BMWi (2011). Energieszenarien 2011: Projekt Nr. 12/10 des Bundesministeriums für Wirtschaft und Technologie (BMWi). Available online at: http://www.prognos. com/fileadmin/pdf/publikationsdatenbank/11_08_12_Energieszenarien_2011. pdf (accessed April 18, 2019).

BMWi (2014). Entwicklung der Energiemärkte: Energiereferenzprognose. Studie im Auftrag des Bundesministeriums Studie im Auftrag des Bundesministeriums BMWi (Projekt Nr. 57/12). Available online at: http://www.bmwi.de/ Redaktion/DE/Publikationen/Studien/entwicklung-der-energiemaerkteenergiereferenzprognose-endbericht.pdf (accessed May 28, 2019). 
BMWi (2015). Interaktion EE-Strom, Wärme und Verkehr: Analyse der Interaktion zwischen den Sektoren Strom, Wärme/Kälte und Verkehr in Deutschland in Hinblick auf steigende Anteile fluktuierender Erneuerbarer Energien im Strombereich unter Berücksichtigung der europäischen Entwicklung. Ableitung von optimalen strukturellen Entwicklungspfaden für den Verkehrs- und Wärmesektor. Gefördert mit Mitteln des Bundesministeriums für Wirtschaft und Energie (BMWi) (Förderkennzeichen 0325444A-C). Available online at: http://www.iee.fraunhofer.de/content/dam/iwes-neu/energiesystemtechnik/ de/Dokumente/Veroeffentlichungen/2015/Interaktion_EEStrom_Waerme_ Verkehr_Endbericht.pdf (accessed May 28, 2019).

BMWi (2018). Langfristszenarien für die Transformation des Energiesystems in Deutschland. Studie im Auftrag des Bundesministeriums für Wirtschaft und Energie (BMWi). Available online at: http://www.bmwi.de/Redaktion/DE/ Artikel/Energie/langfrist-und-klimaszenarien.html (accessed May 18, 2019).

Boysen, L. R., Lucht, W., Gerten, D., Heck, V., Lenton, T. M., and Schellnhuber, H. J. (2017). The limits to global-warming mitigation by terrestrial carbon removal. Earth's Future 5, 463-474. doi: 10.1002/2016EF000469

BUND (2015). Grundlagen und Konzepte einer Energiewende 2050. Available online at: http://www.bund.net/fileadmin/user_upload_bund/publikationen/ klimawandel/klima_energie_energiewendekonzept.pdf (accessed September 26, 2019).

Bundeskanzleramt (2019). Pressekonferenz von Bundeskanzlerin Merkel und dem Ministerpräsidenten des Königreichs der Niederlande, Mark Rutte: 16. Mai 2019. Available online at: http://www.bundeskanzlerin.de/bkinde/aktuelles/pressekonferenz-von-bundeskanzlerin-merkel-und-demministerpraesidenten-des-koenigreichs-der-niederlande- mark-rutte- 1612118 (accessed May 18, 2020).

Bundestag (2002). Endbericht Nachhaltige Energieversorgung unter den Bedingungen der Globalisierung und der Liberalisierung: Drucksache 14/9400. Available online at: http://dip21.bundestag.de/dip21/btd/14/094/1409400.pdf (accessed April 18, 2019).

Cherubini, F., and Strømman, A. H. (2011). Life cycle assessment of bioenergy systems: State of the art and future challenges. Bioresour Technol. 102, 437-451. doi: 10.1016/j.biortech.2010.08.010

dena (2018). dena-Leitstudie Integrierte Energiewende: Impulse für die Gestaltung des Energiesystems bis 2050: Teil B - Gutachterbericht. Available online at: https://www.dena.de/fileadmin/dena/Dokumente/Pdf/9261_dena-Leitstudie_ Integrierte_Energiewende_lang.pdf (accessed April 16, 2019).

EnBW, EON Energie RWE Power, and Vattenfall Europe (2009). Energiezukunft 2050: Teil II - Szenarien. Studie im Auftrag von EnBW, EON Energie, RWE Power und Vattenfall Europe. Available online at: http://www.ffe.de/download/ berichte/Endbericht_Energiezukunft_2050_Teil_II.pdf (accessed May 21, 2019).

ExxonMobil (2011). Energieprognose Deutschland 2011-2030. Available online at: http://www.forschungsnetzwerk.at/downloadpub/Energieprognose_2011.pdf (accessed April 17, 2019).

ExxonMobil (2012). Energieprognose Deutschland 2012-2040. Available online at: http://services.exxonmobil.de/downloads/Energieprognose_2012.pdf (accessed April 17, 2019).

ExxonMobil (2016). Energieprognose Deutschland 2016-2040. Available online at: http://cdn.exxonmobil.com/ /media/germany-natural-gas/files/ publikationen/energie/energieprognose-2040.pdf (accessed April 17, 2019).

ExxonMobil (2018). Energieprognose Deutschland 2018-2040. Available online at: http://cdn.exxonmobil.com/ /media/germany/files/energieprognose/ exxonmobil_energiegrognose_2018.pdf (accessed April 08, 2019).

Fargione, J. E., Bassett, S., Boucher, T., Bridgham, S. D., Conant, R. T., CookPatton, S. C., et al. (2018). Natural climate solutions for the United States. Sci. Adv. 4:eaat1869. doi: 10.1126/sciadv.aat1869

Forster, P. M., Huppmann, D., Kriegler, E., Mundaca, L., Smith, C., Rogelj, J., et al. (2018). "Mitigation pathways compatible with $1.5^{\circ} \mathrm{C}$ in the context of sustainable development: Supplementary material," in Global Warming of $1.5^{\circ} \mathrm{C}$ : An IPCC Special Report on the Impacts of Global Warming of $1.5^{\circ} \mathrm{C}$ Above Pre-industrial Levels and Related Global Greenhouse Gas Emission Pathways, in the Context Of Strengthening the Global Response to the Threat of Climate Change, Sustainable Development, And Efforts To Eradicate Poverty (Geneva: IPCC).

Fraunhofer ISE (2012). 100 \% erneuerbare Energien für Strom und Wärme in Deutschland. Available online at: http://www.ise.fraunhofer.de/content/dam/ ise/de/documents/publications/studies/studie-100-erneuerbare-energienfuer-strom-und-waerme-in-deutschland.pdf (accessed April 18, 2019).
Fraunhofer ISE (2013). Energiesystem Deutschland 2050: Sektor- und Energieträgerübergreifende, modellbasierte, ganzheitliche Untersuchung zur langfristigen Reduktion energiebedingter $\mathrm{CO}_{2}$-Emissionen durch Energieeffizienz und den Einsatz Erneuerbarer Energien. Available online at: http://www. ise.fraunhofer.de/content/dam/ise/de/documents/publications/studies/ Fraunhofer-ISE_Energiesystem-Deutschland-2050.pdf (accessed April 18, 2019).

Fraunhofer ISE (2015). Was kostet die Energiewende? Wege zur Transformation des deutschen Energiesystems bis 2050. Henning, Hans-Martin; Palzer, Andreas. Available online at: http://www.fraunhofer.de/content/dam/zv/ de/Forschungsfelder/Energie-Rohstoffe/Fraunhofer-ISE_TransformationEnergiesystem-Deutschland_final_19_11\%20(1).pdf (accessed April 12, 2019).

FVEE (2010). Energiekonzept 2050: Eine Vision für ein nachhaltiges Energiekonzept auf Basis von Energieeffizienz und $100 \%$ erneuerbaren Energien. Available online at: http://www.fvee.de/fileadmin/politik/10.06.vision fuer_nachhaltiges_energiekonzept.pdf(accessed May 21, 2019).

Gelsenwasser, Open Grid Europe, and RheinEnergie (2017). Energiemarkt 2030 und 2050: Der Beitrag von Gas- und Wärmeinfrastruktur zu einer effizienten $\mathrm{CO}_{2}$-Minderung. Studie im Auftrag von Gelsenwasser, Open Grid Europe und RheinEnergie. Available online at: http://www.ewi.research-scenarios. de/cms/wp-content/uploads/2017/11/ewi_ERS_Energiemarkt_2030_2050.pdf (accessed May 21, 2019).

Greenpeace (2007). Klimaschutz: Plan B: Nationales Energiekonzept bis 2020. Studie wurde im Auftrag von Greenpeace durchgeführt von EUtech Energie und Management. Available online at: http://www.greenpeace.de/sites/www. greenpeace.de/files/publications/energiewende_final_neu2.pdf (accessed April $02,2019)$.

Greenpeace (2010). Klimaschutz: Plan B 2050: Energiekonzept für Deutschland. Studie wurde im Auftrag von Greenpeace durchgeführt von EUtech Energie und Management. Available online at: http://www.greenpeace.de/sites/www. greenpeace.de/files/plan_b_2050_lang_0.pdf (accessed April 02, 2019).

Greenpeace (2015). Klimaschutz: Der Plan: Energiekonzept für Deutschland. Available online at: http://www.greenpeace.de/sites/www.greenpeace.de/files/ publications/klimaschutz-der-plan-greenpeace-20151117.pdf (accessed April $02,2019)$.

Greenpeace (2018). Wie Deutschland sein Klimaziel noch erreichen kann: Teilergebnisse eines $1,5^{\circ} \mathrm{C}$-Szenarios. Studie wurde im Auftrag von Greenpeace durchgeführt von Fraunhofer IEE. Available online at: http://www.greenpeace. de/sites/www.greenpeace.de/files/publications/energieszenario_fuer_2020.pdf (accessed April 02, 2019).

Griscom, B. W., Adams, J., Ellis, P. W., Houghton, R. A., Lomax, G., Miteva, D. A., et al. (2017). Natural climate solutions. Proc. Natl. Acad. Sci. U.S.A. 114, 11645-11650. doi: 10.1073/pnas.1710465114

Haller, M., Repenning, J., Vogel, M., Schlomann, B., Reitze, F., Schön, M., et al. (2016). Überblick über vorliegende Szenarienarbeiten für den Klimaschutz in Deutschland bis 2050. Arbeitspaket 1.1 im Forschungs- und Entwicklungsvorhaben des Bundesministeriums für Umwelt, Naturschutz, Bau und Reaktorsicherheit: Wissenschaftliche Unterstützung "Erstellung und Begleitung des Klimaschutzplans 2050" für das FKZ UM 1541 1860. Available online at: http://www.oeko.de/oekodoc/2445/2016-602-de.pdf (accessed January 16, 2020).

Hansen, K., Mathiesen, B. V., and Skov, I. R. (2019). Full energy system transition towards $100 \%$ renewable energy in Germany in 2050. Renew. Sust. Energy Rev. 102, 1-13. doi: 10.1016/j.rser.2018.11.038

Heck, V., Gerten, D., Lucht, W., and Popp, A. (2018). Author Correction: Biomass-based negative emissions difficult to reconcile with planetary boundaries. Nat. Clim. Change 8:345. doi: 10.1038/s41558-0180107-z

IPCC (ed.). (2018). Global warming of $1.5^{\circ} \mathrm{C}$ : An IPCC Special Report on the Impacts of Global Warming of $1.5^{\circ} \mathrm{C}$ Above Pre-industrial Levels and Related Global Greenhouse Gas Emission Pathways, in the Context of Strengthening the Global Response to the Threat of Climate Change, Sustainable Development, and Efforts to Eradicate Poverty. Geneva.

IPCC (2019). "Summary for Policymakers," in Climate Change and Land: An IPCC Special Report On Climate Change, Desertification, Land Degradation, Sustainable Land Management, Food Security, and Greenhouse Gas Fluxes In Terrestrial Ecosystems, eds P. R. Shukla, J. Skea, E. Calvo Buendia, V. Masson-Delmotte, H.-O. Pörtner, D. C. Roberts, et al. (Geneva).

IRENA (2015). Renewable Energy Prospects: Germany: REmap 2030 Analysis. Available online at: http://www.irena.org/-/media/Files/IRENA/Agency/ 
Publication/2015/IRENA_REmap_Germany_report_2015-(1).pdf (accessed June 13, 2019)

Kornelius, S., Fried, N., and Oltermann, P. (2019). Merkel: Europe Must Unite to Stand Up to China, Russia and US: German Chancellor Also Shares Views on Brexit and Climate Crisis in Interview. Available online at: http://www. theguardian.com/world/2019/may/15/angela-merkel-interview-europe-euunite-challenge-us-russia-china (accessed May 18, 2020).

Kronenberg, T., Martinsen, D., Pesch, T., Sander, M., Fischer, W., Hake, J.-F., et al. (2011). Energieszenarien für Deutschland: Stand der Literatur und methodische Auswertung. Available online at: http://www.fz-juelich.de/SharedDocs/ Downloads/IEK/IEK-STE/EN/report_13_2011.pdf?__blob=publicationFile (accessed November 19, 2019).

Kühne, O., and Weber, F. (2017). Conflicts and negotiation processes in the course of power grid extension in Germany. Landsc. Res. 43, 529-541. doi: 10.1080/01426397.2017.1300639

Kunze, C., and Hertel, M. (2017). Contested deep geothermal energy in Germanythe emergence of an environmental protest movement. Energy Res. Soc. Sci. 27, 174-180. doi: 10.1016/j.erss.2016.11.007

Langer, K., Decker, T., Roosen, J., and Menrad, K. (2018). Factors influencing citizens' acceptance and non-acceptance of wind energy in Germany. J. Clean. Product. 175, 133-144. doi: 10.1016/j.jclepro.2017.11.221

Lenton, T. M. (2014a). "Chapter 3. the global potential for carbon dioxide removal," in Geoengineering of the Climate System, eds R. Harrison, and R. Hester (Cambridge: Royal Society of Chemistry), 52-79. doi: 10.1039/9781782621225-00052

Lenton, T. M. (2014b). The potential for land-based biological CO2 removal to lower future atmospheric CO2 concentration. Carbon Manage. 1, 145-160. doi: $10.4155 / \mathrm{cmt} .10 .12$

Minx, J. C., Lamb, W. F., Callaghan, M. W., Bornmann, L., and Fuss, S. (2017). Fast growing research on negative emissions. Environ. Res. Lett. 12:35007. doi: 10.1088/1748-9326/aa5ee5

Neukirch, M. (2016). Protests against German electricity grid extension as a new social movement? A journey into the areas of conflict. Energ. Sustain. Soc. 6:13. doi: 10.1186/s13705-016-0069-9

Peter, M., Bertschmann, D., and Lückge, H. (2017). Metastudie nationale Energieszenarien und deutsche Energiepolitik. Im Auftrag des Umweltbundesamtes, Forschungskennzahl 371246 103. Available online at: http://www.umweltbundesamt.de/sites/default/files/medien/ 1410/publikationen/2017-11-06_climate-change_27-2017_metastudieenergieszenarien.pdf (accessed November 19, 2019).

Petticrew, M., and McCartney, G. (2011). Using systematic reviews to separate scientific from policy debate relevant to climate change. Am. J. Prevent. Med. 40, 576-578. doi: 10.1016/j.amepre.2010.12.022

Renn, O. (2017). Das Energiesystem resilient gestalten: Szenarien Handlungsspielräume - Zielkonflikte. München; Halle (Saale); Mainz: Deutsche Akademie der Technikwissenschaften e.V; Deutsche Akademie der Naturforscher Leopoldina e.V; Union der Deutschen Akademie der Wissenschaften e.V.

Reusswig, F., Braun, F., Heger, I., Ludewig, T., Eichenauer, E., and Lass, W. (2016). Against the wind: local opposition to the German energiewende. Utilities Policy 41, 214-227. doi: 10.1016/j.jup.2016.02.006

Runkel, M. (2018). Literaturrecherche zu Studien, die eine Dekarbonisierung der Stromerzeugung und anderer Anwendungsbereiche in Deutschland, Europa und weltweit untersuchen. Im Auftrag des Umweltbundesamtes, Projektnummer 75030. Available online at: http://www.umweltbundesamt.de/sites/default/ files/medien/1410/publikationen/2018-06-05_climate-change_14-2018_ dekarbonisierung.pdf (accessed November 19, 2019).

Samadi, S., Terrapon-Pfaff, J., Lechtenböhmer, S., and Knoop, K. (2019). Longterm low greenhouse gas emission development strategies for achieving the 1.5 ${ }^{\circ} \mathrm{C}$ target - insights from a comparison of German bottom-up energy scenarios. Carbon Manage. 9, 549-562. doi: 10.1080/17583004.2018.1475174

Schmid, E., and Knopf, B. (2012). Ambitious mitigation scenarios for Germany: a participatory approach. Energy Policy 51, 662-672. doi: 10.1016/j.enpol.2012.09.007

Shell (2017). Shell Energie Szenarien Deutschland. Available online at: http://www.shell.de/medien/shell-publikationen/energieszenarien/_ jcr_content/par/relatedtopics_8666.stream/1505305389981/ dadc5c9800ca13cc2e7a5f4682b326a3487901b82efa6891053ad51ef4004edf/ german-etcc-brochure.pdf (accessed April 08, 2019).
SRU (2011). Wege zur 100\% erneuerbaren Stromversorgung: Sondergutachten. Berlin: Schmidt Verlag.

Szarka, N., Eichhorn, M., Kittler, R., Bezama, A., and Thrän, D. (2017). Interpreting long-term energy scenarios and the role of bioenergy in Germany. Renew. Sust. Energ. Rev. 68, 1222-1233. doi: 10.1016/j.rser.2016. 02.016

Turner, P. A., Field, C. B., Lobell, D. B., Sanchez, D. L., and Mach, K. J. (2018). Unprecedented rates of land-use transformation in modelled climate change mitigation pathways. Nat. Sust. 1, 240-245. doi: 10.1038/s41893-0180063-7

UBA (2008). Politikszenarien für den Klimaschutz IV: Szenarien bis 2030. Studie erstellt durch Öko-Institut, IEF-STE, DIW und Fraunhofer ISI (Forschungskennzahl 20546434). Available online at: http://www. umweltbundesamt.de/sites/default/files/medien/publikation/long/3361. pdf (accessed April 08, 2019).

UBA (2009). Politikszenarien für den Klimaschutz $V$ - auf dem Weg zum Strukturwandel: Treibhausgas-Emissionsszenarien bis zum Jahr 2030. Studie erstellt durch Öko-Institut, IEF-STE, DIW und Fraunhofer ISI (Forschungskennzahl 20642106). Available online at: http://www. umweltbundesamt.de/sites/default/files/medien/publikation/long/3764. pdf (accessed April 08, 2019).

UBA (2010). Energieziel 2050: 100\% Strom aus erneuerbaren Quellen. Available online at: http://www.umweltbundesamt.de/sites/default/files/medien/378/ publikationen/energieziel_2050.pdf (accessed June 11, 2019).

UBA (2013a). Modellierung einer vollständig auf erneuerbaren Energien basierenden Stromerzeugung im Jahr 2050 in autarken, dezentralen Strukturen. Available online at: http://www.umweltbundesamt.de/sites/default/files/ medien/376/publikationen/climate_change_14_2013_modellierung_einer_ vollstaendig_auf_erneuerbaren_energien.pdf (accessed July 19, 2019).

UBA (2013b). Politikszenarien für den Klimaschutz VI: TreibhausgasEmissionsszenarien bis zum Jahr 2030. Studie erstellt durch Öko-Institut, IEF-STE, DIW und Fraunhofer ISI (Forschungskennzahl 370941109). Available online at: http://www.umweltbundesamt.de/sites/default/files/medien/461/ publikationen/4412.pdf (accessed April 08, 2019).

UBA (2014). Treibhausgasneutrales Deutschland im Jahr 2050. Available online at: http://www.umweltbundesamt.de/sites/default/files/medien/ 378/publikationen/07_2014_climate_change_dt.pdf (accessed May 28, 2019).

UBA (2018). Politikszenarien für den Klimaschutz VII: TreibhausgasEmissionsszenarien bis zum Jahr 2035. Studie erstellt durch Öko-Institut und Fraunhofer ISI (Forschungskennzahl 3714411040). Available online at: http:// www.umweltbundesamt.de/sites/default/files/medien/1410/publikationen/ 2018-01-11_climate-change_01-2018_politikszenarien-vii.pdf (accessed April 08, 2019).

UBA (2019a). Den Weg zu einem treibhausgasneutralen Deutschland ressourcenschonend gestalten: 2. Auflage mit methodischen Anpassungen und Teilneuberechnung in Kapitel 2 und 3. Available online at: http://www. umweltbundesamt.de/sites/default/files/medien/376/publikationen/190215 uba_fachbrosch_rtd_bf.pdf (accessed April 17, 2019).

UBA (2019b). Wege in eine ressourcenschonende Treibhausgasneutralität RESCUE. Available online at: http://www.umweltbundesamt.de/sites/default/ files/medien/376/publikationen/rescue_studie_cc_36-2019_wege_in_eine_ ressourcenschonende_treibhausgasneutralitaet.pdf (accessed December 05, 2019).

WWF (2009). Modell Deutschland - Klimaschutz bis 2050: Vom Ziel her denken. Die Studie wurde erstellt von Öko-Institut und Prognos. Available online at: http://www.wwf.de/fileadmin/fm-wwf/Publikationen-PDF/WWF_Modell_ Deutschland_Endbericht.pdf (accessed April 02, 2019).

Conflict of Interest: The authors declare that the research was conducted in the absence of any commercial or financial relationships that could be construed as a potential conflict of interest.

Copyright $\odot 2020$ Hahn, Szarka and Thrän. This is an open-access article distributed under the terms of the Creative Commons Attribution License (CC BY). The use, distribution or reproduction in other forums is permitted, provided the original author(s) and the copyright owner(s) are credited and that the original publication in this journal is cited, in accordance with accepted academic practice. No use, distribution or reproduction is permitted which does not comply with these terms. 